\title{
The division of labor need not imply regional specialization
}

article version: accepted manuscript

Leppälä, Samuli

Desrochers, Pierre

Samuli Leppälä, Pierre Desrochers, The division of labor need not imply regional specialization, Journal of Economic Behavior \& Organization, Volume 74, Issues 1-2, May 2010, Pages 137-147, ISSN 0167-2681, https://doi.org/10.1016/i.jebo.2010.02.006.

(c)

\section{HOW TO CITE TSPACE ITEMS}

Always cite the published version, so the author(s) will receive recognition through services that track citation counts, e.g. Scopus. If you need to cite the page number of the TSpace version (original manuscript or accepted manuscript) because you cannot access the published version, then cite the TSpace version in addition to the published version using the permanent URI (handle) found on the record page. 


\title{
THE DIVISION OF LABOR NEEDS NOT IMPLY REGIONAL SPECIALIZATION
}

\begin{abstract}
The regional specialization of economic activities is generally deemed desirable for three reasons: 1) the law of comparative advantage; 2) localized economies of scale; and 3) knowledge spillovers. Taking a methodological individualist perspective, we claim that: 1) the law of comparative advantage, while valid for individuals and firms, does not necessarily imply regional specialization when regions are viewed as consisting of heterogeneous individuals; 2) localized economies of scale are seldom specific to one industry and external in all but the regional level; and 3) the study of knowledge spillovers is inconclusive and would benefit from a more disaggregated perspective.
\end{abstract}

Keywords: regional specialization, comparative advantage, economies of scale and scope, knowledge spillovers.

JEL codes: R11, R58, O18, L25. 


\section{Introduction}

The division of labor can be envisaged at the individual, social and spatial levels (Scott, 1986). The first refers to individuals specializing in different tasks within a firm, while in the second case specialization occurs between independent firms. Finally, the spatial level refers to firms specializing in the production of the same type of commodities or services at different geographical scales. The spatial division of labor is thus akin to regional economic specialization and is viewed as a preferable outcome, whether through spontaneous market processes or deliberate public policy planning, by analysts and policy makers who invoke either the efficient geographical allocation of scarce resources through trade or, in the case of dense networks of related firms (such as Silicon Valley), a self-reinforcing setting for innovative behavior (Johansson and Forslund, 2008).

While empirical observations have long challenged the relevance of this perspective to describe some real-world trade and location patterns, ${ }^{1}$ several arguments also support the greater desirability of more diversified economies. The most common are transportation costs; localized economies of scope (or urbanization economies) which benefit firms in diverse industries; a greater "multiplier effect" when new activities are added to the local economy; greater resilience than specialized regions whose fate rests on the demand for a particular good or service; and "Jacobs" spillovers, i.e., the diffusion and adaptation of technical how-know between different industrial sectors which is said to be facilitated by an economically diversified local economy (Polese, 2005).

We attempt to shed new light on this debate by arguing that the traditional case on behalf of regional specialization is ultimately untenable because of a failure to apply a consistent methodological individualistic perspective to its three main supporting arguments: 1) the law of comparative advantage; 2) localized economies of scale; and 3) knowledge spillovers. Our contention is that while each of these arguments is correct at the individual level, they actually undermine to a large extent the case for regional

\footnotetext{
1 The most pressing, of course, being the "similar-similar problem" in international trade, i.e., "the huge role in world trade played by exchanges of similar products between similar countries" (Krugman, 2009, 561).
} 
specialization. Regions, after all, are not single, acting units but are made up of heterogeneous individuals pursuing their separate ends.

The paper is structured as follows. In section two, we review the basic tenets of methodological individualism and draw some relevant implications for the study of regional economies. Building on this perspective, we then argue that the division of labor should be thought of along the lines of individual skills and firm competencies, rather than final products or industrial classification systems. As such, it is inapplicable to purposeless units such as cities, regions or countries, and therefore needs not imply the regional specialization of economic activities. It is demonstrated that regional specialization is efficient only when it is derivative of individual, not regional, comparative advantages. In section four, the argument that the benefits of decreasing costs support the case for regional specialization is similarly found unconvincing inasmuch as such economies would need implausibly to be internal to a single industry at the regional level and external at the individual, interregional, international and interindustrial levels. We then turn our attention to knowledge creation mechanisms and suggest that the claims that a specialized setting is more (or less) likely to promote the development of new combinations than a more diversified one is problematic inasmuch as analyses at the regional level are unable to unveil processes that actually take place at the individual level. The last section is our conclusion.

\section{Methodological individualism in regional studies}

Methodological individualism is a well recognized, if controversial, principle of inquiry in the social sciences. ${ }^{2}$ Although there are many versions, its central tenets are that all social phenomena are in principle only explicable in terms of individual interactions in which "any one individual acts (rationally) on the basis of his own aims and interests" and "takes into account the existence of other individuals with aims and interests" (Agassi, 1960, 244). In other words, methodological individualism does not

\footnotetext{
${ }^{2}$ While ontological individualism is less disputed, the question of whether methodological individualism necessarily ensues is more controversial. More recent debates on the issue revolve mostly around the analysis of individual interactions. Sometimes methodological individualism is mistakenly associated with ethical or political individualism, but the term was originally coined by the economist Joseph Schumpeter to distinguish it from political individualism (Elster, 1982; Hogdson, 2007; Udenh, 2001).
} 
deny interaction between individuals ("methodological atomism") and its fundamental ontological or metaphysical principle is that all social phenomena result from individual beliefs, purposes and actions and should therefore be explained in terms of individuals and their interactions.

A methodological individualistic perspective can be applied to both firm-level and regional studies, for even though management scholars and regional scientists may study the impact of non-social factors on human activities, their foremost task is ultimately to understand social phenomena such as the spatial concentration of production or innovative activities. We suggest, however, that methodological individualism has more important implications for the study of regions than of firms. Of course, there are several notions of regions and possible ways of identifying or classifying them, such as their physical characteristics or cultural commonalities among their inhabitants. More relevant in the context of this paper, however, are factors such as political institutions ("administrative regions") and selective spatial interactions by economic agents, sometimes across political jurisdictions ("functional regions") (Noronha and Goodchild, 1992). As Behrens and Thisse $(2007,458)$ further observe, regional analysts typically "use interchangeably different, yet equally unclear, words such as locations, regions or places without being aware that they often correspond to different spatial units." Be that as it may, the key issue in our discussion revolves around whether or not regional policy makers should design and try to implement economic specialization policies within their areas of jurisdiction, whatever its geographical size.

While a firm is not an individual unless it is completely operated by one entrepreneur, it is nonetheless a goal-oriented organization with well-defined boundaries that, despite its typically multi-product nature, is built around one or a few core competencies. ${ }^{3}$ Outside the context of a centrally planned system, however, geographical units do not share these fundamental characteristics. ${ }^{4}$ Thus, a consistent application of methodological individualism implies that only individuals and not "learning regions," "regional networks," or "regional systems of innovation" have skills, capabilities and tastes. Besides, unlike firms, geographical units whose boundaries are arbitrarily defined do not enter and exit markets, nor do they produce or trade goods and services, an argument

\footnotetext{
${ }^{3}$ Udehn $(2001,265-272)$ is a more detailed discussion of methodological individualism in the theory of firm.
} 
which similarly applies to countries and therefore to theories of international trade. In short, regions do not act like individuals or even organizations (Boschma, 2004; Frenken and Boschma, 2007). Yet this fundamental difference becomes problematic when, for example, the competing agent is often not clearly defined in the interregional competition literature (Lagendijk and Oinas, 2005). Our contention is that regions do not act at all (but individuals within them do) or compete against each other (whilst individuals within them might).

A methodological individualist perspective on regional growth and development however, does not imply that local attributes have no effect on individual activities, but rather that they do not unilaterally determine what individuals are capable of doing and what they actually do. As the economist Ludwig von Mises (1957, 324-325) pointed out in his discussion of geographical determinism, an individual's surroundings "provides on the one hand a provocation to act and on the other hand both means that can be utilized in acting and insurmountable limits imposed upon the human striving for betterment," but while it "provides a stimulus," it does not provide a response.

The socio-spatial ontology historically favored by most economic geographers however, eschews a strict adherence to methodological individualism (Plummer and Sheppard, 2006). One reason for this intellectual stance could be that the explananda of regional studies is at a somewhat indeterminate "meso-level"5 situated between micro and macro levels. Another is a rejection of a perspective according to which economic actors are assumed to be fully rational or autonomous and empirical tools too confining for the analysis of complex space-economies (Plummer and Sheppard, 2006). A methodological stance that treats individuals as the basic agents of change however, does not necessarily imply any specific assumptions about their beliefs, preferences and interactions, nor about how to incorporate these into mathematically defined economic models (Arrow, 1994).

Again, our fundamental argument is that individuals, not spatially defined entities, are the appropriate level of analysis, a less controversial claim. Of course, abstraction is often necessary, while acting collective units, such as regions or countries, can be helpful

\footnotetext{
4 Krugman (1994) essentially conveys this point in his critique of the frequent practice of treating competition between nations and firms in a similar fashion.
} 
metaphors or examples (Behrens and Thisse, 2007). As a critic of the dominant version of methodological individualism among economists points out however, attributing intent to collectives is a misleading and often unsatisfactory explanatory short cut (Hodgson, 1986).

Our methodological take will therefore include both firms and individuals as acting units. While being usually more than one entrepreneur, the firm is nevertheless a legal entity and a contracting party that is created for a specific goal(s). It is usually made up of several individuals whose specialized tasks and skills are required to accomplish particular ends. The firm's organizational capabilities, or routines, are directly affected by individual skills (Nelson and Winter, 1982, 124), while regions and other geographical units, however, do not share this connection with individuals. In addition, from the perspective of most other economic actors the firm is typically seen as a single entity which is why, in our opinion, it can be studied in accordance with a methodological individualistic perspective within the context of regional economies. Of course, such a perspective would be inadequate to study its inner dynamics and spin-offs created by departing employees.

In short, the perspective put forth in this paper is not merely ontological since we do not insist that every study should depart from the individualistic level, but rather methodological as we argue that an individualistic perspective should be adopted when aggregation affects the derived results. Thus, we suggest that disaggregation becomes necessary when causal explanations are sought in the context of regional growth and development, as will now be illustrated.

\section{Comparative advantage and regional specialization}

David Ricardo's law of comparative advantage and Adam Smith's division of labor are often treated by analysts as being superficially similar, as both arguments support the geographical specialization of economic activities. There are, however, important differences between Smithean and Ricardian logics and analysis (Buchanan and Yoon,

\footnotetext{
5 Note that we are referring here to a spatial meso-level, whereas in evolutionary economic geography "meso" typically refers to rule systems (Dopfer et al. 2004) or networks and sectors (Boschma and Frenken, 2006). There is a connection between these concepts, however, since they usually operate at local or regional levels.
} 
2002). While Smith explained his idea in terms of individuals and might not have viewed foreign trade as being intrinsically different than trade between individuals (Maneschi, 1998), Ricardo dealt with countries that exchanged goods. According to Smith, trade emerges because specialization is productive due to increasing returns that do not necessarily result from individual differences. In other words, even two individuals possessing similar intellectual and physical endowments will find it advantageous to specialize in the production of different goods, as both will become increasingly efficient over time, and achieve a higher standard of living through trade. In short, for Smith, individual differences were the consequence, not the cause, of the division of labor (Cannan, 1893).

In the Ricardian framework ${ }^{6}$ however, "specialization and subsequent trade become advantageous because of the inherent differences among potential trading parties" (Buchanan and Yoon, 2002, 400). In other words, two (or more) countries are better off when each specializes in producing one product and trades the surplus for the other product(s) than they would be in a state of autarky, but only if their opportunity costs differ. In this context, it does not matter if one trading party is better in producing all commodities (i.e., has an absolute advantage in producing every commodity) than the other, since both will always have a comparative advantage in one particular product. By specializing in the production of the goods in which they are relatively better (or least disadvantaged), they can both benefit from transacting with the other. Only transportation costs are an exception to the rule that specialization is the desirable outcome, thus leading to the existence of non traded goods sectors.

The belief that regional specialization is the beneficial outcome of market processes was logically derived from the application of the law of comparative advantage at the sub-national level. This is a general feature of regional economics, where many models and techniques are mere extensions of those used at the national level (Behrens and Thisse, 2007). For example, the economist Leland Yeager (1954, non-paginated) argues that, along with improved transportation, free trade "promotes interregional specialization and increases through trade the results that a country gets from its productive powers." As could be observed at the time of his writing: "Iowa raises corn 
and hogs, Virginia grows tobacco, and Massachusetts makes shoes. Iowans get their tobacco and shoes from Virginia and Massachusetts, paying in part with money earned by selling corn and hogs outside the state. The people of Virginia and Massachusetts likewise import many products, paying in part with products they do make." The geographer G. T. Renner $(1955,511)$ expressed this idea most forcefully ${ }^{7}$ when he stated that with increased commercial competition, "any region will, unless prevented from doing so by political controls, tend to specialize in the production of those commodities for which it possesses a natural or technological advantage" and that "wherever there are several alternative uses for land and other resources, that use which is most advantageous will be selected." Reflecting the widespread influence of Porter's (1990) "cluster" framework, Karlsson and Stough $(2002,1)$ wrote more recently that economic development "is no longer a question of national specialization and competitive power but of regional specialization often based on clusters and geographical competitive advantages."

The traditional case for comparative advantage has been challenged most prominently by factor based models (Heckscher-Ohlin), the infant industry argument and more dynamic models that all invoke some form of increasing returns. We will now suggest, however, that the apparent incompatibilities of perspectives based on increasing returns and (inherent or learned) differences between acting units can be resolved by a consistent application of the principle of comparative advantage to its logical end (i.e., the individual level), in the process undermining the alleged benefits of regional specialization.

Table 1 illustrates such an outcome in the context of two regions ( $A$ and $B)$, each capable of producing and trading two commodities (computers and medicine), and each consisting of two individual subunits $\left(a_{1}, a_{2} \subseteq A\right.$ and $b_{1}, b_{2} \subseteq B$ ). The numbers in Table 1 represent the maximum amount of computers and medicine that can be produced in a certain amount of time. What a region can produce is the sum of what individuals in the region are capable of producing. In the chosen example, these two regions are perfect

\footnotetext{
${ }^{6}$ Robert Torrens shares the credit of discovering the principle and it was Haberler who later formulated it in terms of opportunity costs (Maneschi, 1998). Interestingly, and contrary to the textbook version, Ricardo had diminishing returns of labor in mind and never suggested complete specialization (Maneschi, 1998, 59).

${ }^{7}$ Renner (1955) doesn't specify what type of advantage he has in mind to back up his argument. .
} 
mirror images of each other. Region $A$ has a comparative advantage in producing medicine $\left(\frac{15}{18}<\frac{18}{15}\right)$, whereas $B$ has a comparative advantage in producing computers ${ }^{8}$.

\section{(Table 1 around here)}

Table 1. Maximum production capacities of computers and medicine

In light of regional comparative advantages, region $A$ should specialize in producing medicine and region $B$ in producing computers, resulting in the more desirable total output of 18 computers and 18 units of medicine. As expected, the division of labor in this case delivers a bigger pie as a result of specialization and trade. As will now be argued however, this situation is not optimal. If each individual in region A and B was to specialize according to their individual comparative advantages, world production could be even larger; $a_{1}$ and $b_{2}$ could thus produce 10 computers, whereas $a_{2}$ and $b_{1}$, by specializing in the production of medicine, could produce 10 units of the latter. The total world production would therefore be 20 computers and 20 units of medicine, higher for both goods than would be the case under the conventional regional specialization scenario.

How is this result derived? Our example does not question the validity of comparative advantage and specialization when there are differences in opportunity costs. We argue however, that these differences should be analyzed at the most disaggregated level possible. This example could be criticized on the basis that there are more agents than goods, but the case against regional specialization would also hold in $n$-good and $n$-agent models ${ }^{9}$. Otherwise, it is conceivable that some commodities would not be produced.

If regions within a country differ in terms of comparative advantages, they should specialize according to those differences. The same logic holds true, however, when individuals within a region are heterogeneous, i.e., specialization should ultimately come down to the individual level. In theory, regional specialization is optimal only when the individuals within a region have the same comparative advantage, as compared to the

\footnotetext{
${ }^{8}$ In the example, the comparative advantages are also absolute advantages, but this does not affect the results.
} 
individuals in another region (see Appendix A for the proof). Even in such a case however, regional specialization is derivative of individual specialization, not the other way around.

Individual comparative advantages are partly affected by their local or regional circumstances. For this reason, it could be that theoreticians, from Ricardo who did not explain the origins of technological differences (or labor productivities) between countries to the more recent models offered by Fujita, Krugman and Venables (1999), have mostly discussed comparative advantages in terms of geographical attributes, especially in the context of agricultural production. Besides natural factors (landscape, climate, mineral endowments, etc.), however, individual comparative advantages are also determined by skills, technical know-how and human capital, whichever concept one prefers, that can also vary within a region. It would be reasonable to expect their importance to be significant, especially in the context of a modern service-oriented or "knowledge-intensive" economy.

The optimality of regional specialization becomes increasingly unlikely if we consider comparative advantages in dynamic, rather than static, circumstances ${ }^{10}$. Changing demand and supply factors can transfer the comparative advantage from one product or service to another. Individual skills are not static either. Individuals might not just improve in terms of what they have been doing up to one point in time, but they might also find their talents or skills useful in another setting or line of work. In the course of time, new production possibilities appear. Therefore, even if regional specialization happened to be the derivative of individual specialization, it would likely remain so only temporarily.

Recently, Unger (2007, Ch. 2) criticized the "doctrine" of comparative advantage on the grounds that there are multiple possible solutions depending on the choice of the model, while no considerations of dynamic properties or different institutional settings are included. As a result, no top-down blueprint is possible and no answer can be given as to what production a given country or region should specialize in. However, our contention is that the actual division of labor should be a bottom-up process, and that the

\footnotetext{
${ }^{9}$ See Deardorff (2005) for list of assumptions under which comparative advantage does and does not hold.

${ }^{10}$ According to Maneschi (1998), while a useful pedagogical device, the textbook 'Ricardian' model does not do full justice to Ricardo's insights into the dynamic aspects of international trade.
} 
law of comparative advantage, if useless as a specific policy guide, nonetheless retains its value as a vehicle for conveying the mutually beneficial character of trade.

To summarize, while fundamentally correct at the individual level, the law of comparative advantage is too easily taken as a sufficient argument for regional specialization. This in turn, opens the doors to skeptics such as Driskill (2007) for whom the argument for the mutually beneficial character of trade collapses, because individualmodel analogies are inadequate for actual trading situations where several heterogeneous individuals are involved. Again, our position is not the latter, but rather that regional specialization can only be theoretically efficient when individuals within a region possess the same comparative advantages.

\section{Localized economies of scale and scope}

While regional specialization is in most cases inefficient from the perspective of individual opportunity costs and aggregate output, one could argue that such inefficiencies could be countered by the positive externalities generated as an outcome of individuals congregating in different locations on the basis of identical or closely related skills. Such a perspective can be found in Krugman's (1987) dynamic model of comparative advantage based on the concept of 'learning-by-doing' (Arrow 1962a) ${ }^{11}$. One rationale for increasing returns is thus localized economies of scale.

In the case of an individual firm, economies of scale arise in a situation "when the increased size of a single operating unit producing or distributing a single product reduces the unit cost of producing or distributing" (Chandler, 1990, 17). In a regional economy, localized economies of scale arise when the addition of a new firm in a region reduces unitary costs for all firms in the region. This cost reduction takes place indirectly via reduced costs of skilled labor, intermediate inputs, transportation, financing, marketing, infrastructure, etc., as a result of increasing demand for these products and services when they are characterized by decreasing marginal costs.

Since regional specialization implies a concentration of several similar firms, the mere existence of decreasing costs is clearly insufficient in this respect. As Maskell (2001) has

\footnotetext{
${ }^{11}$ Krugman's argument can be summarized as follows: "It is not the case that nations specialize in what they are good at so much as they are good at what they specialize in" (Pinch and Henry, 1999, 816).
} 
noted, an agglomeration theory of localized economies of scale should explain why there is a cluster of $\mathrm{N}$ co-localized firms of size $\mathrm{S}$ undertaking related activities, rather than a single firm of size $\mathrm{N} x \mathrm{~S}$ producing the same goods or services. In other words, these economies of scale need to be external to a firm but internal to a region, otherwise a firm could achieve identical results simply by expanding its output, in which case there would be nothing regional about these economies (see also Parr, 2002). As Stigler $(1951,186)$ put it, if economies are internal to an industry, then the resulting organizational configuration would tend towards monopoly. For regional specialization to be an optimal outcome, however, such economies also need to be local and thus unattainable beyond regional boundaries.

By analogy, Ethier (1979) has demonstrated in the case of international trade that if increasing returns depend upon the size of the world market rather than national output, the tendency towards interindustry specialization disappears and intraindustry trade in intermediate goods emerges. The perfect internalization of localized economies of scale would require immobility of labor and intermediate goods between regions. In addition, it is less clear whether the cost of a skilled labor force would be lower when $\mathrm{N}$ colocalized firms are competing for it. Conversely, a single firm of size $\mathrm{N}$ x S would have some monopsony power in the labor market. Again, the assumption underlying localized economies of scale seems to be that a region is a coherent acting unit, while no attention is paid to realistic microfoundations.

To make this point more apparent localized economies of scale can be broken down in two distinct categories, localization and urbanization economies, with the former being available to all local firms within the same sector whereas the latter are available to all local firms irrespective of sector (Parr, 2002). Therefore, only localization economies are specific to regional specialization, whereas urbanization economies are achieved by mere agglomeration, irrespective of the line of work local firms are active in. Yet there is often a connection between agglomeration and diversity. As increasing agglomeration tends to reduce the degree of specialization (Ricci 1999), growing cities, just like growing mature ecosystems, tend to get more diversified over time (Jacobs, 1969).

Inasmuch as localization economies are not urbanization economies, human capital and other inputs must be specific to only one industry. If however, these inputs can be used profitably elsewhere, they yield localized economies of scope. In the case of individual firms, economies of scope are "those resulting from the use of processes within a single operating unit to produce or distribute more than one product" (Chandler, 
1990, 17). At the regional level, the geographical concentration of firms engaged in diverse lines of work can sometimes achieve a similar result, a phenomenon now sometimes referred to as Jacobs externalities (Frenken et al. 2007) ${ }^{12}$. Localized economies of scope occur from making use of the same raw and semifinished materials and the same intermediate processes, such as distribution or marketing, to "handle more than a single product line" (Chandler, 1990, 41). Since research and development is even less product specific in terms of facilities and organizational capabilities, the opportunities to exploit economies of scope are even greater (ibid.). If however, economies of scope are internal to a firm, the result should theoretically be a multiproduct firm (Panzar and Willig, 1981). Hence localized economies of scope should be external to firms, providing a rationale for firms to co-locate.

But as in the case of similar co-located firms, this begs the question as to why several firms are operating within one product chain rather than simply merging into one large vertically integrated firm, or several firms producing different products rather than one multi-product firm. While the relationship between organization and transaction costs has typically been used to explain the former (Coase, 1937), it might be that the gains from the (social) division of labor could be another part of the answer; expanding the activity beyond one's core competencies could mean facing increased costs as economies of scope are thus external to a firm.

In the case of localized economies, labor and other inputs must de facto be so specialized that they cannot be used in production, distribution or research in other lines of work. Such a situation makes these suppliers completely dependent on the parent industry. However, the driving force in the growth of the modern industrial enterprise and industrial capitalism has been to exploit organizationally based competitive advantages such as economies of scope (Chandler, 1990). In other words, firm managers continually and actively look for such economies, as well as opportunities to work with or expand into different industries; a rationale which can ultimately be traced back to newly generated know-how with other potential applications (Teece, 1980) ${ }^{13}$. We thus

\footnotetext{
${ }^{12}$ Frenken and Boschma $(2007,642)$ note that Jacobs externalities are economies of scope at the regional level. The explanation for such a macro phenomenon should however stem from economies of scope at the individual level. In the following section, we further distinguish such "Jacobs externalities" from the geographically localized interindustrial knowledge diffusion process referred to as "Jacobs spillovers."

${ }^{13}$ This idea comes close to so called 'related variety' (Frenken et al. 2007). However, it should be kept in mind that due to generic skills and know-how, different industries can be related in many ways, most of which are indirect.
} 
suggest that regional diversity provides arguably better circumstances for the discovery and development of new economies of scope when the required resources to exploit them are relatively more accessible.

Localized economies of scope are arguably harder to detect than localized economies of scale. This feature is even stronger when these economies are built on know-how that is not easily observable to outsiders. For example, firms active in different industries can use the same inputs, networks, distribution channels and specialized consultants, or else produce goods and services for each others' use. There are numerous possibilities in this respect and it is less clear why the benefits of agglomeration would necessarily be greater when all firms are engaged in the production of similar outputs. At this point, the debate is an empirical question and the effect of localization economies must be compared with those of localized economies of scope, which are due to facilitative industries or other industrial interrelationships (Renner, 1947).

Often forgotten in abstract discussions of regional economic infrastructure, however, is the fact that, by their very nature, some production activities directly benefit from the co-location of dissimilar production activities. Most striking in this respect is a type of linkage now typically referred to as "industrial symbiosis" in which the unavoidable residuals of one line of work become the valuable input of another (Chertow, 2000; Jacobsen, 2006). Although often thought of as a recent phenomenon, much historical evidence suggests that industrial symbiosis is as ancient as economic activity. To give a few historical illustrations, glue factories were often located in close proximity to meatpacking and fish processing plants in order to have easy access to their non-edible residuals. Some cement and glass plants were built adjacent to steel producers in order to use their slag. The origins of countless firms in the modern petro-chemical industry can be traced back to ventures that initially fed on the residuals of coal gas and petroleum refining operations (Desrochers, 2008; 2009.

Interestingly, the recent "rediscovery" of industrial symbiosis paved the way for a few planning exercises through which public officials attempted to develop local economies around by-product linkages. While so-called "eco-industrial parks" have typically failed to live up to expectations in practice (Deutz and Gibbs, 2004), their planning stage has nonetheless highlighted the fact that specialization-oriented cluster development is fundamentally incompatible with the spontaneous emergence of industrial symbiosis. Indeed, a recurring argument in this literature is that local diversity increases the 
probabilities of developing commercially successful symbiotic relationships (Korhonen, 2005; Templet, 1999, 2004; Wells and Darby, 2006).

It seems that while the relative importance of localized economies of scale and scope is ultimately an empirical question, it once again leads us back to the issue of whether skills (or human capital) used in the production of certain final goods, along with services and capacities used for the production of intermediate goods for those industries, are bound to be so specialized that they cannot be used in other lines of work. While such specificity varies between industries, our contention is that the opposite is often truer. Many functions in firms are performed by specialists such as sales and marketing people, accountants, $R \& D$ personnel, engineers and technicians with particular expertise, and so on. These occupations show a deep division of labor at the individual level, but they can be used in a wide variety of businesses and industries. For suppliers, specialization in cross-cutting base processes, base components or base services enables the development and retention of large and diverse customer bases (Sturgeon, 2002). Indeed, as Alfred Marshall $(1923,10)$ observed last century in the context of industrial machinery:

Modern work is more narrowly specialized, in so far as the number and variety of the operations performed by a modern worker are on the average less than those of elementary skilled handicraftsman; but it is less narrowly specialized, in the sense than an operative, who has mastered the accurate, delicate and prompt control of machinery of any kind in one industry, can now often pass, without great loss of efficiency, to the control of similar machinery in an industry of a wholly different kind, and perhaps working on different material.

As argued above, a dynamic view of localized economies of scope implies that firms are constantly looking for new ways to put their specific capabilities to new uses. In addition to cost advantages, firms and individuals might adopt this strategy for 'portfolio' reasons, as they do not want to become too dependent on one product line due to changing demand conditions, new competition, or potential offshoring. Again, it is logical to believe that firms will be in a better position to find and develop new economies of scope in a diverse region due to perceptible local opportunities.

While the above remarks deal mostly with supply-side issues, it should be appreciated that demand conditions, i.e. the extent of the market, were important for Adam Smith's argument on behalf of the benefits of the division of labor. First, with nonhomothetic 
preferences, consumption patterns will change as income grows, resulting correspondingly in more diversified production patterns (Imbs and Wacziarg, 2003). Second, when markets expand due to potential trading partners, greater specialization becomes feasible. Through wider markets, individuals can specialize in completely new tasks. This process however, implies specialization within societies, not between them. Thus, the increasing division of labor due to expanding markets à la Adam Smith suggests that a larger market makes individual specialization feasible, but not that regions should become more specialized ${ }^{14}$. This proposition is further supported by the first formal research on the mutual dependence between the division of labor and the extent of the market, demonstrating that firms become more specialized when the total population increases (Zhou, 2004) ${ }^{15}$.

The division of labor is not the same as regional specialization. Indeed, Kim (2006) has proposed that the former should be measured by the level of industrial diversification. Many studies have suggested that it would be beneficial for firms to locate in cities and industrial regions characterized by a pre-existing abundance of other firms. However, since there are many sources for agglomeration economies, finding evidence of their existence is not the same as identifying their source (Hanson, 2001). Congruently, neither should the empirical fact of the existence of specialized regions be taken as an evidence of the superiority of regional specialization. As could perhaps be expected, empirical studies on agglomeration economies seem very context-dependent (Melo et al., 2009). To gain better understanding of the sources of these economies, studies at the firm-level, rather than at the aggregate or regional level are called for.

\section{$5 \quad$ Knowledge spillovers}

In their influential paper, Glaeser et al. (1992) sum up "dynamic" arguments on behalf of industrial agglomeration under the heading of MAR (for the insights of economists Marshall 1890, Arrow 1962a and Romer 1986), (management scholar) Porter (1990) and

\footnotetext{
14 According to Richardson (2003, 92-93): "Later theorists responsible for the model of perfect competition, so influential since its development a century after Smith, in effect rejected this famous principle [the division of labor is limited by the extent of the market] by assuming the existence of many firms doing the same thing."
} 
(urban theorist) Jacobs (1969) knowledge spillovers. Since knowledge spillovers are especially sensitive to the "friction of distance," they provide a rationale for firms engaged in the same or similar industry to co-locate, with the primary intermediating mechanism in diffusing knowledge usually thought to be interacting skilled labor within the industry. MAR and Porter spillovers are similar inasmuch as they occur within the same industry, but differ to the extent that the former suggest that large and resource-rich firms are most likely to capture them, while the latter views a region with numerous small and fiercely competing firms as the best incubator. By contrast, Jacobs spillovers are based on the idea that innovation results from new combinations and "new work being added to old" across different industries, often through the interaction of people possessing different skill sets and know how. Jacobs spillovers thus support the contention that a diverse region will be more innovative.

Malmberg and Maskell (2002) consider knowledge creating mechanisms a more valid explanation for agglomeration than cost savings. Variation between different firms, both at the horizontal and vertical levels, creates knowledge which is too extensive to be captured in its entirety by a single firm, no matter its size. Additionally, the tacit or unarticulable character of much useful knowledge and the importance of face-to-face interaction in its communication is said to explain why knowledge spillovers occur mostly within regional boundaries. ${ }^{16}$

Tacit knowledge usually refers to skills, capacities or unconscious dispositions to act, but it remains unclear why these would be key components of innovative behavior. A more plausible view is that while much knowledge could be codified (i.e., turned to information), "being there" displaces this need and delivers the same (or better) results at a fraction of the cost. Individuals working for a firm can observe novel ideas being developed in particular circumstances and learn spontaneously without searching for new knowledge (Malmberg and Maskell, 2002). For insiders, there might not be any incentive to codify and distribute this knowledge, while outsiders would first have to know what to look for before they could search for it. In addition, it would be hard, if not impossible,

\footnotetext{
15 The total number of goods however, is exogenously given in the model. Without such restrictions, individual specialization and the heterogeneity of production patterns would most likely increase.

${ }^{16}$ It must be pointed out, however, that the concept of tacit knowledge has long been criticized on several counts. For example, is tacit knowledge uncodifiable in principle or is it simply difficult to codify (Brökel and Binder, 2007, 153-154)? Perraton and Tarrant (2007, 354) go so far as stating that tacit knowledge "is merely a term given to a phenomenon that the observer does not understand; as such, it has no explanatory content."
} 
for third parties to act as intermediaries and trade the knowledge due to Arrow's (1962b) information paradox ${ }^{17}$.

Much empirical work has been conducted on the relative importance of intra- and interindustrial knowledge spillovers, and both types have found support in different contexts (Döring and Schnellenbach, 2006). Partially due to this lack of decisive results, new approaches that would be more squarely based in methodological individualism (without using the exact term) have been called for. Hansen $(2002,261)$ thus writes that regions, networks and information technologies are innate entities that cannot learn or innovate, and that "more meaningful analyses" would require "disaggregated empirical studies of how knowledge in fact passes among persons." Similarly, Breschi and Lissoni (2001) describe localized knowledge spillovers as a 'black box,' since studies on the topic do not prove or even document their existence. In their opinion, this debate would benefit from "additional evidence on the identity and the activities of individual firms and inventors" (ibid. 1001). In short, more disaggregated data and hypotheses on how knowledge in fact passes among individuals, the effect of regional factors on these processes, and how these processes ultimately result in greater innovativeness, would reduce the discrepancy between empirical and theoretical models.

At the moment researchers are perplexed about what knowledge is transferred, how it is transferred, and what the role of the local economy is in this respect (e.g. Brenner, 2007; Henderson, 2007). Studying how individuals innovate by recombining different know-how and artifacts can nonetheless shed much light on the issue. Using as our point of departure Jacobs' insight, we conducted a qualitative survey of individual inventors in which we identified three broad, although not mutually exclusive, sets of circumstances through which individuals found new uses or applications for existing products and created new combinations of existing products, processes and materials: 1) by adding to, switching or adapting specific know-how to other lines of work; 2) by observing something in another line of work and incorporating it into one's own line of work; and 3) through formal and informal multidisciplinary teams working towards the creation of new products and processes (Desrochers and Sautet, 2007).

17 "[T]here is a fundamental paradox in the determination of demand for information; its value for the purchaser is not known until he knows the information, but then he has in effect acquired it without cost." (ibid. 615) 
Besides studying the individual creative process, taking account of differences between and within industries could also shed more light on the debate (Oinas and Lagendijk, 2005). Be that as it may, a case can be made that current knowledge spillovers research is caught in a circular causality bind similar to the cost advantage argument. In other words, while knowledge spillovers supposedly explain the existence of agglomeration, the geographical agglomeration of economic activities is now taken as evidence of the existence of knowledge spillovers.

\section{Conclusion}

Our goal in this paper was to examine critically the arguments traditionally used to make the case for the regional specialization of economic activities through the consistent application of the principle of methodological individualism. Cast in this light, comparative advantage was found problematic when regions are viewed as consisting of heterogeneous individuals. Indeed, if individuals differ in terms of opportunity costs, a consistent application of the principle of comparative advantage reveals that regional specialization becomes inefficient. Gains from specialization or the division of labor are reaped when all individuals in a society specialize in things they do best (in a comparative sense), not when everyone specializes in doing the same thing. It is specialization according to individual, not regional, comparative advantages which guarantees efficiency.

What then should be the role of regional policy when specialization is a matter of individual comparative advantages? In our opinion, the relevant question becomes "who knows these comparative advantages best?" Following Hayek's (1948) seminal writings, we suggest that it is very difficult and rare for individuals working for a central planning authority to know more or even as much as all the individuals living within a particular polity. While we may grant the (heroic) assumption that a group of experts knows the overall maximum production of different commodities, and can thus establish regional comparative advantages on this basis, our demonstration suggests that top-down regional specialization would only deliver the optimal outcome when every individual within the region possesses the same comparative advantage. In all other circumstances, "bottomup" market processes through which individuals specialize according to their

comparative advantages would result in a greater degree of diversity. The law of 
comparative advantage is therefore not a sound justification for publicly planned regional specialization. This does not mean that regional specialization can never be beneficial; indeed, there are plenty of well-documented cases of thriving regional clusters. Our claim is only that regional specialization should not be viewed as the ultimate goal for policy makers. Furthermore, most persistent regional clusters have arisen largely spontaneously, at least in their initial stage (Desrochers and Sautet, 2004).

In a dynamic economy where individual comparative advantages are constantly being created and lost, the challenges for regional policy are even more profound. Regional specialization policy thus increases the danger of lock-in and weakens the capacity of local actors to adjust to changing circumstances. Again, we believe that individuals as economic agents are better equipped to notice and create new opportunities than any centralized authority, and that advantage is increased when people differ in terms of perspectives, backgrounds and abilities (Heath, 2007).

In addition to geographical differences, cost advantages can be achieved through specialization in the presence of decreasing costs. Arguably, sharing the cost of infrastructure is beneficial from a firm's perspective, but such structures are seldom unique to an industry. Furthermore, in addition to be specific to an industry, localized economies of scale should be somehow internal to a regional setting, but external to a firm or to any spatial unit larger than a region. To be satisfactory as a causal factor, localized economies of scale would need to explain the additional benefits they provide to what individual firms can achieve by themselves.

Knowledge creation mechanisms, such as knowledge spillovers, are arguably more internalized through close geographical proximity and a more convincing explanation for agglomerative tendencies. Recent empirical tests, however, have found support for both intra- and interindustrial spillover theories, while being unable to document their existence. Interestingly, while knowledge spillovers were supposed to explain the existence of industrial agglomeration, the ubiquitous fact of industrial agglomeration is now invoked to prove the existence of knowledge spillovers. More disaggregated approaches are hence called for.

Assuming that our analysis is correct, we will now venture a rejoinder to the Nobel laureate Paul Samuelson's (1969, 9) 'comparative advantage' answer to the mathematician Stanislaw Ulam's challenge to name "one proposition in all of the social sciences which is both true and non-trivial." Samuelson argument was on the following grounds: "That it is logically true need not be argued before a mathematician; that it is 
not trivial is attested by the thousands of important and intelligent men who have never been able to grasp the doctrine for themselves or to believe it after it was explained to them." And yet, while it is true and non-trivial in the context of individuals, such as Samuelson's famous example of the best lawyer/typist in town, it does not logically follow that the same holds true in the context of regions or nations. Indeed, what "many intelligent men (and women)" have probably always objected to is the subsequent step in the argument that regions or nations should similarly specialize in one commodity or service that will inevitably be subjected to economic downturns and/or decrease in economic value over time. In the end, it might be that this apparently trivial insight has escaped generations of economists.

\section{Acknowledgements}

Research for this paper was made possible by a grant from the Social Sciences and Humanities Research Council of Canada (SSHRC). 


\section{References}

Agassi, J., 1960. Methodological individualism. British Journal of Sociology 11, 244 270.

Arrow, K., 1962a. The economic implications of learning by doing. Review of Economic Studies 29, 155-173.

Arrow, K., 1962b. Economic welfare and the allocation of resources to invention. In: Nelson, R.R. (Ed.) The Rate and Direction of Inventive Activity: Economic and Social Factors. Princeton University Press, Princeton. 609-626.

Arrow, K., 1994. Methodological individualism and social knowledge. American Economic Review 84, 1-9.

Behrens, K., Thisse, J., 2007. Regional economics: A new economic geography perspective. Regional Science and Urban Economics 35, 457-465.

Boschma, R., 2004. Competitiveness of regions from an evolutionary perspective. Regional Studies 38, 1001-1014.

Boschma, R., Frenken, K., 2006. Why is economic geography not an evolutionary science? Towards an evolutionary economic geography. Journal of Economic Geography 6, 273-302.

Brenner, T., 2007. Local knowledge resources and knowledge flows. Industry and Innovation 14, 121-128.

Breschi, S., Lissoni, F., 2001. Knowledge spillovers and local innovation systems: A critical survey. Industrial and Corporate Change 10, 975-1005.

Brökel, T., Binder, M., 2007. The regional dimension of knowledge transfers-a behavioral approach. Industry and Innovation 14, 151-175.

Buchanan, J., Yoon, Y., 2002. Globalization as framed by the two logics of trade. The Independent Review 6, 399-405. 
Cannan, E., 1893. A History of the Theories of Production and Distribution in English Political Economy from 1776 to 1848. Augustus M. Kelley Publishers, New York 1967.

Chandler, A.D., Jr., 1990. Scale and Scope: The Dynamics of Industrial Capitalism. Harvard University Press, Cambridge, MA 1994.

Chertow, M. 2000. Industrial symbiosis: Literature and taxonomy. Annual Review of Energy and the Environment 25, 313-337

Coase, R.H., 1937. The nature of the firm. Economica 4, 386-405.

Deardorff, A.V., 2005. How robust is comparative advantage? Review of International Economics 13, 1004-1016.

Desrochers, P. 2008. Did the invisible hand need a regulatory glove to develop a green thumb? Some historical perspective on market incentives, win-win innovations and the Porter yypothesis. Environmental and Resource Economics 41, 519-539.

Desrochers, P. 2009. Does the invisible hand have a green thumb? Market incentives and the development of wealth from industrial waste in Victorian England. Geographical Journal 175, 3-16.

Desrochers, P., Sautet, F. 2004. Cluster-based economic strategy, facilitation policy and the market process. Review of Austrian Economics 17, 233-245

Desrochers, P., Sautet, F. 2007. Policy environments that best enable entrepreneurship: The case of regional specialization Vs spontaneous industrial diversity" Entrepreneurship: Theory \& Practice 32, 813-832.

Deutz, P., Gibbs, D., 2004. Eco-industrial development and economic development: Industrial ecology or place promotion? Business Strategy and the Environment 13, 346-362.

Dopfer, K., Foster, J., Potts, J., 2004. Micro-meso-macro. Journal of Evolutionary Economics 14, 263-279. 
Döring, T., Schnellenbach, J., 2006. What do we know about geographical knowledge spillovers and regional growth?: A survey of the literature. Regional Studies 40, 375-395.

Driskill, R., 2007. Deconstructing the argument for free trade. Working paper. Available at: http://www.vanderbilt.edu/econ/faculty/Driskill/Deconstructing2008Feb 09.pdf (Last accessed February $2^{\text {nd }}, 2010$ ).

Elster, J., 1982. The case for methodological individualism. Theory and Society 11, 453482.

Ethier, W., 1979. Internationally decreasing costs and world trade. Journal of International Economics 9, 1-24.

Frenken, K., Boschma, R., 2007. A theoretical framework for evolutionary economic geography: Industrial dynamics and urban growth as a branching process. Journal of Economic Geography 7, 635-649.

Fujita, M., Krugman, P., Venables, A.J., 1999. The Spatial Economy: Cities, Regions, and International Trade. MIT Press, Cambridge.

Frenken, K., Oort, F., van, Verburg, T., 2007. Related variety, unrelated variety and regional economic growth. Regional Studies 41, 685-697.

Glaeser, E.L., Kallal, H.D., Scheinkman, J.A., Shleifer, A., 1992. Growth in cities. Journal of Political Economy 100, 1126-1152.

Hansen, N., 2002. Dynamic externalities and spatial innovation diffusion: Implications for peripheral regions. International Journal of Technology, Policy and Management 2, 260-271.

Hanson, G.H., 2001. Scale economies and the geographic concentration of industry. Journal of Economic Geography 1, 255-276.

Hayek, F.A., 1948. Individualism and Economic Order. University of Chicago Press, Chicago. 
Heath, W.C., 2007. Hayek revisited: Planning, diversity, and the vox populi. The Independent Review 12, 47-70.

Henderson, J.V., 2007. Understanding knowledge spillovers. Regional Science and Urban Economics 37, 497-508.

Hodgson, G., 1986. Behind methodological individualism. Cambridge Journal of Economics 10, 211-224.

Hodgson, G., 2007. Meanings of methodological individualism. Journal of Economic Methodology 14, 211-226.

Imbs, J., Wacziarg, R., 2003. Stages of diversification. American Economic Review 93, 63-86.

Jacobs, J., 1969. The Economy of Cities. Random House, New York.

Jacobsen, N.B., 2006. Industrial symbiosis in Kalundborg, Denmark. A quantitative assessment of economic and environmental aspects. Journal of Industrial Ecology 10, 239-255.

Johansson, B., Forslund, U., 2008. The analysis of location, colocation and urbanization economies. In: Karlsson, C. (Ed.) Handbook of Research on Cluster Theory, Vol. 1. Edward Elgar, Cheltenham. 39-66.

Karlsson, C., Stough, R.R., 2002. Introduction: Regional policy evaluation in the new economic geography. In: Johansson, B., Karlsson, C., Stough, R.R. (Eds.) Regional Policies and Comparative Advantage. Edward Elgar, Cheltenham. $1-21$.

Kim, S., 2006. Division of labor and the rise of cities: Evidence from US industrialization, 1850-1880. Journal of Economic Geography 6, 469-491.

Korhonen, J., 2005. Theory of industrial ecology: The case of the concept of diversity. Progress in Industrial Ecology 2, 35-72.

Krugman, P., 1987. The narrow moving band, the Dutch disease, and the competitive consequences of Ms. Thatcher: Notes on trade in the presence of dynamic scale economies. Journal of Development Economics 27, 41-55. 
Krugman, P., 1994. Competitiveness — a dangerous obsession. Foreign Affairs 73, 28-44.

Krugman, P., 2009. The increasing returns revolution in trade and geography. American Economic Review 99, 561-571.

Lagendijk, A., Oinas, P., 2005. Proximity, external relations, and local economic development. In: Lagendijk, A., Oinas, P. (Eds.) Proximity, Distance, and Diversity: Issues on Economic Interaction and Local Development. Ashgate, Aldershot. 3-22.

Malmberg, A., Maskell, P., 2002. The elusive concept of localization economies: Towards a knowledge-based theory of spatial clustering. Environment and Planning A 34, 429-449.

Maneschi, A., 1998. Comparative Advantage in International Trade: A Historical Perspective. Edward Elgar, Cheltenham.

Marshall, A., 1890. Principles of Economics. $8^{\text {th }}$ edition. London: MacMillan 1953. Available at: http://www.econlib.org/library/Marshall/marP.html (Last accessed August 5th, 2009).

Marshall, A., 1923. Industry and Trade. MacMillan and Co., London.

Maskell, P., 2001. Towards a knowledge-based theory of the geographical cluster. Industrial and Corporate Change 10, 921-943.

Melo, P.C., Graham, D.J., Noland, R.B., 2009. A meta-analysis of estimates of urban agglomeration economies. Regional Science and Urban Economics 39, $332-342$.

Mises, L., von, 1957. Theory and History: An Intepretation of Social and Economic Evolution. Ludwig von Mises Institute, Auburn 1985.

Nelson, R.R., Winter, S.G., 1982. An Evolutionary Theory of Economics Change. Belknap Press of Harvard University Press, Cambridge, MA. 
Noronha, V.T., Goodchild, M.F., 1992. Modeling interregional interaction: Implications for defining functional regions. Annals of the Association of American Geographers 82, 86-102.

Oinas, P., Lagendijk, A., 2005. Towards understanding proximity, distance and diversity in economic interaction and local development. In: Oinas, P., Lagendijk, A. (Eds.) Proximity, Distance, and Diversity: Issues on Economic Interaction and Local Development. Ashgate, Aldershot. 307-331.

Panzar, J.C., Willig, R.D., 1981. Economies of scope. American Economic Review 71, $268-272$.

Parr, J.B., 2002. Missing elements in the analysis of agglomeration economies. International Regional Science Review 25, 151-168.

Perraton, J., Tarrant, I., 2007. What does tacit knowledge actually explain? Journal of Economic Methodology 14, 353-370.

Pinch, S., Henry, N., 1999. Paul Krugman's geographical economics, industrial clustering and the British motor sport industry. Regional Studies 33, 815827.

Plummer, P., Sheppard, E., 2006. Geography matters: Agency, structures and dynamics at the intersection of economics and geography. Journal of Economic Geography 6, 619-637.

Polese, M., 2005. Cities and national economic growth: A reappraisal. Urban Studies 42, 1429-1451.

Porter, M., 1990. The Competitive Advantage of Nations. The Macmillan Press, London.

Renner, G.T., 1947. Geography of industrial localization. Economic Geography 23, 167189.

Renner, G.T., 1955. Principles and laws of economic geography. In: Dohrs, F.E. (Ed.) Outside Readings in Geography. Thomas Y. Crowell New York 1958. 506514. 
Richardson, G.B., 2003. Differentiation and continuity in the market economy. In: Koppl, R. (Ed.) Austrian Economics and Entrepreneurial Studies. Advances in Austrian Economics, Vol. 6. Elsevier Science Ltd, Oxford. 89-95.

Ricci, L.A., 1999. Economic geography and comparative advantage: Agglomeration versus specialization. European Economic Review 43, 357-377.

Romer, P.M., 1986. Increasing returns and long-run growth. Journal of Political Economy 94, 1002-1037.

Samuelson, P.A., 1969. The way of an economist. In: Samuelson, P.A. (Ed.) International Economic Relations: Proceedings of the Third Congress of the International Economic Association. Macmillan, London. 1-11.

Scott, A.J., 1986. Industrial organization and location: Division of labor, the firm, and spatial process. Economic Geography 62, 215-231.

Stigler, G.J., 1951. The division of labor is limited by the extent of the market. Journal of Political Economy 59, 185-193.

Sturgeon, T.J., 2002. Modular production networks: A new American model of industrial organization. Industrial and Corporate Change 11, 451-496.

Teece, D.J., 1980. Economies of scope and the scope of the enterprise. Journal of Economic Behavior and Organization 1, 223-247.

Templet, P.H., 1999. Energy, diversity and development in economic systems; An empirical analysis. Ecological Economics 30, 223-233.

Templet, P.H., 2004. Diversity and other emergent properties of industrial economies. Progress in Industrial Ecology 1, 24-38.

Udehn, L., 2001. Methodological Individualism: Background, History, and Meaning. Routledge, London.

Unger, R.M., 2007. Free Trade Reimagined: The World Division of Labor and the Method of Economics. Princeton University Press, Princeton. 
Wells, P.E., Darby, L., 2006. Re-writing the ecological metaphor, Part 2: The example of diversity. Progress in Industrial Ecology 3, 129-147.

Yeager, L.B., 1954. Free Trade: America’s Opportunity. Robert Schalkenbach

Foundation, New York. Available at: http://oll.libertyfund.org/title/2038

(Last accessed August 5th, 2009).

Zhou, H., 2004. The division of labor and the extent of the market. Economic Theory 24, 195-209. 


\section{Appendix A}

\section{Regional Specialization and Individual Opportunity Costs}

The following is to demonstrate that regional comparative advantage is not sufficient in itself for regional specialization to be efficient. As illustrated, this can only be the case when all individuals within the region have a comparative advantage in the commodity in which the region specializes.

In this model there are two regions (the second is separated with *) and two individuals within each region. There are also two goods, medicine (m) and computers (c), and the production possibility curve between the two is

$$
Q_{m}^{i}=\frac{L^{i}}{a_{m}^{i}}-\frac{a_{c}^{i}}{a_{m}^{i}} Q_{c}^{i}
$$

The production of each region is the sum of the production of individuals within the region $Q_{m}=Q_{m}^{1}+Q_{m}^{2}$ and $Q_{m}^{*}=Q_{m}^{* 1}+Q_{m}^{* 2}$ (and similarly for computer production).

We assume that the first region has comparative advantage in computer production

$$
\frac{a_{c}}{a_{m}} \leq \frac{a_{c}^{*}}{a_{m}^{*}}
$$

Our target function is the overall production of medicine

$$
Q_{m}+Q_{m}^{*}=\frac{L^{1}}{a_{m}^{1}}-\frac{a_{c}^{1}}{a_{m}^{1}} Q_{c}^{1}+\frac{L^{2}}{a_{m}^{2}}-\frac{a_{c}^{2}}{a_{m}^{2}} Q_{c}^{2}+\frac{L^{* 1}}{a_{m}^{* 1}}-\frac{a_{c}^{* 1}}{a_{m}^{* 1}} Q_{c}^{*_{1}}+\frac{L^{* 2}}{a_{m}^{* 2}}-\frac{a_{c}^{* 2}}{a_{m}^{* 2}} Q_{c}^{* 2}
$$

The inequality constraint is $Q_{c}^{1}+Q_{c}^{2}+Q_{c}^{* 1}+Q_{c}^{* 2} \geq \frac{L^{1}}{a_{c}^{1}}+\frac{L^{2}}{a_{c}^{2}}$,

which means that the computer production has to be at least as much as when both individuals within the first region produce only computers. 
If the optimal solution is such that the first region specializes in computers $\left(Q_{c}^{1}=\frac{L^{1}}{a_{c}^{1}}, Q_{c}^{2}=\frac{L^{2}}{a_{c}^{2}}\right)$ and the second in medicine $\left(Q_{c}^{* 1}=Q_{c}^{* 2}=0\right)$, from the first order conditions we get that $-\frac{a_{c}^{1}}{a_{m}^{1}}+\lambda=-\frac{a_{c}^{2}}{a_{m}^{2}}+\lambda=0$ and therefore $\lambda=\frac{a_{c}^{2}}{a_{m}^{2}}=\frac{a_{c}^{1}}{a_{m}^{1}}$. Since other conditions tell us that $-\frac{a_{c}^{* 1}}{a_{m}^{* 1}}+\lambda \leq 0$ and $-\frac{a_{c}^{*_{2}}}{a_{m}^{* 2}}+\lambda \leq 0$, we have that $\frac{a_{c}^{1}}{a_{m}^{1}} \leq \frac{a_{c}^{*_{1}}}{a_{m}^{* 1}}$, $\frac{a_{c}^{1}}{a_{m}^{1}} \leq \frac{a_{c}^{* 2}}{a_{m}^{* 2}}, \frac{a_{c}^{2}}{a_{m}^{2}} \leq \frac{a_{c}^{* 1}}{a_{m}^{* 1}}$ and $\frac{a_{c}^{2}}{a_{m}^{2}} \leq \frac{a_{c}^{* 2}}{a_{m}^{* 2}}$.

Regional specialization is efficient only when both individuals within the region have a comparative advantage in the good in which they are specialized compared to both individuals in the other region. 